Bardhoshi, G. \& Duncan, K. (2009). Rural school principals’ perceptions of the school counselor’s role. The Rural Educator, 30(3), 16-24.

\title{
Rural School Principals’ Perception of the School Counselor's Role
}

\author{
Gerta Bardhoshi \\ Stephen F. Austin State University \\ Kelly Duncan \\ University of South Dakota
}

Responding to the lack of clarity related to the defined role of the school counselor, the authors investigated school principals $(n=538)$, in a rural Midwest state, and their perceptions of the role of the school counselor. The survey utilized was developed based on professional standards of service delivery for professional school counselors as identified by the American School Counselor Association and a listing of identified appropriate and inappropriate school counselor tasks. Results indicate that school principals see responsive service provision as an essential task of the school counselor. School principals also perceive a number of ASCA identified inappropriate tasks as being important. Recommendations are made to further enhance school principals' understanding of the appropriate role of the school counselor.

\section{Introduction}

Over the years, the profession of school counseling has faced a lack of clarity regarding the school counselor's role, function and identity. A review by Murray (1995) indicates that the role of the school counselor reflects a history of unclear definition and confusion. As societal changes, educational reforms, and new needs and demands continually shape the profession, many, including administrators, are left confused as to the main purpose of a school counselor (Ballard \& Murgatroyd, 1999).

Although professional school counselors and the American School Counseling Association (ASCA) have been focusing on reconfiguring the identity of school counselors and expanding it beyond the historical guidance model, incongruence between advocated and actual school counselor duties is evident (Lambie \& Williamson, 2004). As differences of opinions regarding the role of the school counselor still exist among school principals (Shoffner \& Williamson, 2000), it is important to assess this impediment to the establishment of appropriate roles for the school counselor.

Rural school counselors in particular may face unique professional challenges. In its decennial survey, the Census Bureau has defined "rural" as a residual category of places in communities that are not within urban areas, with less than 2,500 inhabitants, or where the population density is less than 1,000 inhabitants per square mile (McLaughling, Huberman \& Hawkins, 1997). For the rural state selected in our research, the U.S. Census Bureau reports a density of 9.9 persons per square mile in the year 2000 (U.S. Census Bureau, 2006). The concept of a rural setting is also applicable to individual schools based on their location. Consequently, a school district is considered rural if the majority of schools in that district are located in areas that are rural. For the state selected in our research, 149 out of the total of 174 school districts were characterized as rural in the year 1993-1994 (McLaughling, Hubberman \& Hawkins, 1997).

School counselors in sparsely populated areas deal with unique issues such as serving as the only school counselor in their district and often being the exclusive mental health professional in their areas (Duncan, 2003). Limited availability of funds needed to create a comprehensive school counseling program, professional isolation, limited access to professional development due to logistical obstacles, and lack of community resources have also been identified in the literature (Morissette, 2000). This renders the assessment of rural school principals' perception of the school counselor role imperative to understanding their actual practices. This study aimed to determine and compare K-12 school principals' perception of the school counselor's role in a Midwestern state categorized geographically as largely rural.

\section{History of School Counseling and School Counselor Appropriate and Inappropriate Duties}

To better understand the nature and extent of this identity confusion, a brief look at the history of school counseling is necessary. Changing forces in society have continually redefined the role and function of the school counselor. Throughout the century-long history of the profession of school counseling, school counselor's roles have expanded and changed according to the focuses of each decade.

The vocational guidance, assessment and academic placement focus of the early $20^{\text {th }}$ century was followed by a shift towards the provision of personal and social counseling services and the inclusion of holistic development that dominated the field during the middle of the century 
(Lambie \& Williamson, 2004). As guidance and counseling leaders struggled to gain control of the school counselor's time and duties, and school counselors failed to define their own standards, school administrators directed counselors according to their own objectives. With the addition of special education services, consultation, coordination and accountability duties that came towards the end of the century, it is easy to understand why school counselors have suffered from an unclear role identity. At the same time, they feel overwhelmed with the many demands that have been placed on them (Lambie \& Williamson, 2004).

A working definition of the vision of the school counselor was expressed in The Education Trust's Transforming School Counseling Initiative presented in 1997 (Education Trust, 1997), which described the role of the school counselor by emphasizing a student achievement focus instead of a mental health one. It also called for a shift away from individual student concerns and towards whole school and system concerns, away from record keeping towards utilizing data for change and focusing on educational equity. Most importantly, it proposed that the role of the school counselor should fall into five domains: Leadership, Advocacy, Teaming and Collaboration, Counseling and Coordination, and Assessment and Use of Data (Pérusse et al, 2004; Sears, 1999).

As a response to the varying themes within the profession and the challenge that school counselors respond to the increasing demands of students and the raised expectations of society, in 1997 ASCA proposed the National Standards for School Counseling Programs (Campbell \& Dahir, 1997). These standards provide the framework for developing a school counseling program, while at the same time serving as a guideline for state departments, local districts and individual schools on how to plan, develop, implement and evaluate a comprehensive school counseling program (Dahir, 2000). They focus on the role of counseling in student achievement and the collaboration between school counselors, school administrators, and teachers in enhancing student success (Baker, 2000). As a result, these standards enlist school counselors as "partners in the teaching and learning process" (Dahir, 2000).

School counseling today continues to be affected by initiatives and educational reforms (Herr, 2001). A recent example of this is President George W. Bush's No Child Left Behind initiative. Current trends indicate that the focus continues to change from students at-risk, to school violence, cost effectiveness and academic achievement (Johnson, 2000). Additionally, school counselors face expectations of involvement in both educational and mental health initiatives, serving increasingly diverse populations and relying on technology. They have the unique opportunity of responding to these challenges by defining their roles appropriately and consistently (Paisley \& McMahon, 2001).

As stated above, school counselors' main resource for defining their roles is the ASCA National Model. In accordance with this professional model, school counselors implement the counseling program by delivering specific services to students, parents, school staff and the community that fall into four common categories: School Guidance Curriculum; Individual Student Planning; Responsive Services; and System Support. It is important to note that there is no allowance for non-counseling activities as they do not fit into the four major service delivery components described above (ASCA, 2003).

School Guidance Curriculum (classroom guidance) provides school counselors with the content, scope and sequence, and instructional strategies needed to deliver the school's overall curriculum. It includes services that address the areas of organizational, study, and test-taking skills; career planning; peer relationships and effective social skills; multicultural awareness; and substance abuse education (ASCA, 2003).

Individual Student Planning focuses on activities that assist students in developing life and career plans based on their skills, aptitudes, and abilities. School counselors serve students and parents as facilitators of student development. It includes services that address education in understanding self and others, academic planning, and transition plans (ASCA, 2003).

Responsive Services consist of activities to meet the immediate needs and concerns of students and are preventative or interventive in nature. The counselor intervenes on behalf of those students whose immediate personal concerns or problems put their continued personal, career, and/or academic development at risk. It includes individual and small group counseling, individual/family/school crisis intervention, consultation/collaboration and referrals (ASCA, 2003).

The final category, System Support, consists of management activities that focus on establishing, maintaining and enhancing the total school counseling program. It includes professional development, consultation, collaboration and teaming, and program management and operation (American School Counselor Association, 2004a). Despite professional standards, literature indicates that school counselors see themselves spending too much time in administrative functions (Baker, 2000). Zalaquett (2005) also states that school counselors participate in duties that are only remotely related to their training and their professional role. One factor that has been repeatedly identified in professional literature as impacting role clarity for school counselors is the inconsistent perception of school professionals, especially school principals (Schmidt, 2003; Baker, 2000; Murray, 1995; Niebuhr, Niebuhr \& Cleveland, 1999; Lieberman, 2004; Ponec \& Brock, 2000) regarding the role of the school counselor. In a study conducted by Pérusse et al (2004), the exact same tasks that were most highly endorsed by school principals were at the same time the most frequently performed inappropriate tasks by school counselors, indicating that school principals do indeed influence the role of the school counselor. 
School administrators may carry the assumption that school counselors should perform duties that although are important in the proper functioning of the school, are not identified as appropriate by the ASCA National Model listings of appropriate duties of a school counselor. Pérusse et al. (2004) report that the administration of tests and maintaining student records is endorsed as appropriate by the majority of secondary school principals. In another study by Fitch et al. (2001), assisting in special education services was also rated as important by the majority of future school administrators. The carrying out of these tasks can prevent school counselors from delivering essential appropriate services and advance confusion regarding the role of the school counselor.

In a study conducted by Amatea \& Clark (2005), one fourth of the study participants (administrators) characterized the school counselor's primary role as that of an administrative team member that is expected to carry out administrative needs and goals. The school counselor was perceived more as a subordinate rather than an expert professional. In another study that assessed the perceptions of practicing school counselors and administrators who had previously taken a course that oriented them to each other's roles, administrators were still more likely to endorse statements incongruent with the role of the school counselor than the counselors (Kirchner \& Setchfield, 2005).

Although some literature indicates that principals have expanded their knowledge on the school counseling program through training and research, many principals continue to base their perception of the role of the school counselor on their own experiences with the counselor from their school years (Coy, 1999). As graduate programs in administration do not always require courses in school counseling or do not necessarily focus on the role of the school counselor and the nature of the comprehensive school counseling program (Fitch at al, 2001; Beale \& McCay, 2001), school principals are not aware of the appropriate roles for the school counselor. As a consequence, principals often formulate a counseling department on minimal expertise that is often based on experience gained through their internship or a previous position (Seashore Louis, Jones \& Barajas, 2001).

\section{Present Study}

Although past research has focused on the functions and duties of school counselors as perceived by school principals across the nation, this study attempted to determine the rural elementary, middle, and high school principals' perception regarding the role of the school counselor. These perceptions were indicated by the rated importance of a variety of appropriate and inappropriate tasks. Research questions were identified as follows:

1. Do rural school principals deem the provision of specific services that fall into the four common
ASCA National Model categories (School Guidance Curriculum, Individual Student Planning, Responsive Services, and System Support) as important to the role of the school counselor?

2. Do rural school principals deem inappropriate counseling tasks based on professional literature as important to the role of the school counselor?

3. To what particular tasks do rural school principals give priority?

This study expected school principals to recognize and deem as important tasks that fall within the four core service categories as defined by the ASCA National Model (School Guidance Curriculum, Individual Student Planning, Responsive Services, and System Support). However, as supported by other studies (Fitch et al, 2001) some inappropriate counseling duties such as maintaining student records, administering cognitive, aptitude and achievement tests, assisting in special education services, and performing disciplinary actions were also expected to be deemed as important by school principals.

The data for this study was obtained through an online questionnaire made available to the entire population of school principals in a rural Midwestern state.

During this period of proliferation in the numbers of larger high schools, many educational leaders and researchers have been considering ways to create smaller units within large high schools. Gregory (2000) identified four societal forces that have driven educators to seek ways to divide large schools into smaller schools. The four leading forces behind the drive to create smaller learning environments are (a) the information age, (b) the emergence of an adolescent culture, (c) the students' rights movement, and (d) our changing views of the proper functioning of organizations. According to Gregory, these four forces have resulted in making large schools less effective than their smaller counterparts.

\section{Method}

\section{Participants}

The entire population of K-12 school principals of a rural state employed in a public or private school setting during the 2005-2006 year was selected as participants for this study. The original population size was composed of 582 school principals, whose email addresses were obtained from the state's Department of Education. After some participant undeliverable email addresses and written requests to not be included in the population, the population size was for the purpose of this study then determined to be $538 \mathrm{~K}-12$ school principals.

The response rate to this survey was $64 \%$. Regarding demographics, $65 \%$ of respondents were males and $35 \%$ 
females. Nearly 93\% of the respondents were white, with 4\% American Indian/ Alaskan Native, and 3\% identified as other/no response. The vast majority of respondents (98\% and $89 \%$ respectively) reported more than five years in education and as a practicing school principal. Nearly $68 \%$ reported holding a masters degree and 61\% reported having taken counseling courses. Nearly 42 of all respondents reported having 200 or less students under their direct responsibility, 49\% reported having 201 to 600 students, and only $9 \%$ reported having more than 600 students. A grade level assignment of elementary school was reported by nearly $39 \%$, middle school by $10 \%$, and high school by $18 \%$. Nearly $7 \%$ reported a grade level assignment of both elementary and middle school, $20 \%$ of both middle and high school and $7 \%$ of all elementary, middle and high school.

\section{Instrumentation}

Participants completed the 2006 Rural School Counselor Role Survey online. The survey consisted of two parts and contained a total of 31 items. Of those items, 11 corresponded to Part I and were demographic in nature. They addressed specific information such as gender, ethnic status, number of years in education, number of years as a practicing school principal, level of the participant's education, the completion of a counseling course, the total number of certified school counselors serving within the school building, the total number of uncertified individuals serving in a school counseling role, the total number of students under the participant's direct responsibility and current grade assignment.

Part II of the survey, which pertained to the school counselor role, contained 20 items. The survey was developed strictly based on professional standards of service delivery for professional school counselors as identified by ASCA (2004b; 2004c; \& 2004d) and a listing of identified appropriate and inappropriate school counselor tasks (Campbell \& Dahir, 1997). All items included in Part II of the survey were word-for-word representations of the contents included in the above sources.

The participants rated the importance of specific tasks based on a 5 -point Likert scale ( $1=$ not at all important; 2 = of little importance; $3=$ moderately important; $4=$ important; and 5 = very important). Thirteen of the sixteen items regarding appropriate duties were selected to represent tasks descriptive of all four of the service delivery categories. Four of the thirteen items pertain to School Guidance Curriculum and include: academic support, including organizational, study and test taking skills; peer relationships, coping strategies and effective social skills; multicultural/diversity awareness; and career awareness, exploration and planning. Two of the thirteen items pertain to Individual Student Planning and include: education on understanding of self, including strengths and weaknesses; and academic planning. Another four of the thirteen items pertain to Responsive Services and include: crisis intervention; small group counseling; individual counseling; and referrals from school support to community resources. Finally, the remaining three of the thirteen items pertain to System Support and included: consultation, collaboration and teaming; school counseling program management and operation; and professional development.

Another question raised during discussions of size was, "HoAn Something is missing here... additional three items describing appropriate tasks include: assisting the school principal with identifying and resolving student issues, needs, and problems; interpretation of cognitive, aptitude and achievement tests; and analyzing grade point averages in relationship to achievement. The final four items related to inappropriate tasks include: maintaining student records; administration of cognitive, aptitude and achievement tests; performing disciplinary actions; and assisting in special education services (beyond referrals or participation in IEP meetings).

Face validity in this questionnaire is provided because it was based on ASCA sanctioned items. However, because the study is descriptive in nature, little reliability information will be available for the survey instrument.

\section{Procedures}

The survey was piloted with a class of 18 graduate students taking a graduate research and design class. Following revisions a second pilot test was conducted with a class of 18 graduate students taking a Current Issues in K-12 Education class.

The survey was constructed in a web format. The webbased questionnaire included a welcome screen instructing participants how to proceed (Dillman, 2000), discussing informed consent, and providing contact information (Nardi, 2006). The survey method employed followed a modified multiple contact procedure suggested by Dillman (2000) regarding internet surveys. All participants received individual email messages for purposes of protecting their confidentiality. No compensation was given for participation in this study.

An analysis was run with the original data as received. Frequencies were computed for each variable and correlations among selected variables were examined in order to describe the degree of their relationship.

\section{Results}

Regarding the four ASCA National Model Service Delivery categories, items falling under the Responsive Services category were rated the highest importance, with following categories being Guidance Curriculum, System Support, and Individual Student Planning. The responsive services category was composed of items crisis intervention; small group counseling; individual counseling; and referrals from school support to community resources. Nearly $93 \%$ of all respondents rated crisis intervention as "important" or 
“very important” and 75\% rated small group counseling as “important” or "very important." Nearly $87 \%$ of all respondents rated individual counseling as "important" or "very important" and $74 \%$ rated referrals from school support to community resources as "important" or "very important.”

The School Guidance Curriculum category was composed of items academic support, including organizational, study and test taking skills; peer relationships, coping strategies and effective social skills; multicultural/diversity awareness; and career awareness, exploration and planning. Nearly $71 \%$ of all respondents rated academic support, including organizational, study and test taking skills as being "important" or "very important" and 92\% rated peer relationships, coping strategies and effective social skills as “important” or "very important." Nearly 63\% of all respondents rated multicultural/diversity awareness as "important" or "very important" and 72\% rated career awareness, exploration and planning as "important" or "very important."
The System Support category was composed of items consultation, collaboration and teaming; school counseling program management and operation; and professional development. Nearly $84 \%$ of all respondents rated consultation, collaboration and teaming as "important" or “very important” and 80\% rated school counseling program management and operation as important. Nearly 53\% of all respondents rated professional development as "important" or "very important."

The Individual Student Planning category was composed of items education on understanding of self, including strengths and weaknesses; and academic planning. Nearly $79 \%$ of all respondents rated education on understanding of self, including strengths and weaknesses as "important” or "very important" and 62\% rated academic planning as “important” or "very important." Further breakdown of responses and groupings by rating of importance per service delivery category are shown in Table 1.

Table 1

Rating of Appropriate Tasks Based on Importance per ASCA per Service Delivery Category

\begin{tabular}{|c|c|c|c|c|c|c|}
\hline \multirow[b]{2}{*}{ Responsive Services } & \multicolumn{3}{|c|}{$\begin{array}{l}\text { Level of importance in } \\
\text { percentages }\end{array}$} & \multicolumn{3}{|c|}{$\begin{array}{l}\text { Level of importance } \\
\text { in frequency }\end{array}$} \\
\hline & $\mathrm{I} / \mathrm{VI}$ & $\mathrm{I}$ & VI & I/VI & $\mathrm{I}$ & VI \\
\hline 1. Crisis intervention & 93.3 & 14.5 & 78.8 & 316 & 49 & 267 \\
\hline 2. Individual counseling & 86.5 & 31.0 & 55.5 & 293 & 105 & 188 \\
\hline 3. Small group counseling & 74.9 & 39.8 & 34.8 & 253 & 135 & 118 \\
\hline 4. Referrals from school support to community resources & 73.7 & 45.4 & 28.3 & 250 & 154 & 96 \\
\hline Guidance Curriculum & $\mathrm{I} / \mathrm{VI}$ & I & VI & I/VI & I & VI \\
\hline $\begin{array}{l}\text { 1. Peer relationships, coping } \\
\text { strategies and effective social skills }\end{array}$ & 91.7 & 33.3 & 58.4 & 311 & 113 & 198 \\
\hline 2. Career awareness, exploration and planning & 72.2 & 39.2 & 33.0 & 245 & 133 & 112 \\
\hline $\begin{array}{l}\text { 3. Academic support, including organizational, study and } \\
\text { test taking skills }\end{array}$ & 70.8 & 38.9 & 31.9 & 240 & 132 & 108 \\
\hline 4. Multicultural/diversity awareness & 62.8 & 41.0 & 21.8 & 211 & 139 & 74 \\
\hline System Support & I/VI & $\mathrm{I}$ & VI & I/VI & $\mathrm{I}$ & VI \\
\hline 1. Consultation, collaboration and teaming & 83.6 & 45.5 & 38.1 & 283 & 154 & 129 \\
\hline 2. School counseling program management and operation & 82.8 & 44.5 & 38.3 & 281 & 151 & 130 \\
\hline 3. Professional development & 52.5 & 36.3 & 16.2 & 178 & 123 & 55 \\
\hline Individual Student Planning & $\mathrm{I} / \mathrm{VI}$ & $\mathrm{I}$ & VI & I/VI & $\mathrm{I}$ & VI \\
\hline $\begin{array}{l}\text { 1. Education on understanding of self, including strengths } \\
\text { and weaknesses }\end{array}$ & 79.0 & 46.3 & 32.7 & 268 & 157 & 111 \\
\hline 2. Academic planning & 61.7 & 38.1 & 23.6 & 209 & 129 & 80 \\
\hline
\end{tabular}

Note. I/VI = Important/Very Important; I = Important; VI = Very Important.

Regarding inappropriate school counseling tasks, nearly $68 \%$ of all respondents rated administration of cognitive, aptitude and achievement tests as "important" or "very important" and 51\% rated assisting in special education services as “important” or "very important." Nearly 48\% rated maintaining student records as "important” or "very important” and 13\% rated performing disciplinary actions as “important” or "very important."

Specific tasks by order of importance were rated as follows: 1) Crisis intervention (93.3\%); 2) Peer relationships, coping strategies and effective social skills (91.7\%); 3) Individual counseling (86.5\%); 4) Assisting the 
school principal with identifying and resolving student issues, needs, and problems (85.5\%); 5) Consultation, collaboration and teaming (83.6\%); 6) School counseling program management (82.8\%); 7) Education on understanding of self, including strengths and weaknesses (79\%); 8) Small group counseling (74.9\%); 9) Referrals from school support to community resources (73.7\%); 10) Career awareness, exploration and planning (72.2\%); 11) Academic support, including organizational, study and test taking skills (70.8\%); 12) Administration of cognitive, aptitude and achievement tests (68.1\%); 13) Interpretation of cognitive, aptitude and achievement tests (67\%); 14) Multicultural/diversity awareness (62.8\%); 15) Academic planning (61.7\%); 16) Professional development (52.5\%); 17) Assisting in special education services (50.7\%); 18) Maintaining student records (48.1\%); 19) Analyzing grade point averages in relationship to achievement (37.4\%); and 20) Performing disciplinary actions (12.7\%). Breakdown of responses regarding the rating of appropriate and inappropriate tasks by order of importance is shown in Table 2.

\section{Table 2}

Rating of Appropriate and Inappropriate Tasks Based on Importance

\begin{tabular}{|c|c|c|c|c|c|c|}
\hline \multirow[b]{2}{*}{ Appropriate and inappropriate tasks } & \multicolumn{3}{|c|}{$\begin{array}{l}\text { Level of importance in } \\
\text { percentages }\end{array}$} & \multicolumn{3}{|c|}{$\begin{array}{l}\text { Level of importance in } \\
\text { frequency }\end{array}$} \\
\hline & I/VI & $\mathrm{I}$ & VI & I/VI & I & $\mathrm{VI}$ \\
\hline 1. Crisis intervention & 93.3 & 14.5 & 78.8 & 316 & 49 & 267 \\
\hline 2. Peer relationships, coping strategies and effective social skills & 91.7 & 33.3 & 58.4 & 311 & 113 & 198 \\
\hline 3. Individual counseling & 86.5 & 31.0 & 55.5 & 293 & 105 & 188 \\
\hline $\begin{array}{l}\text { 4. Assisting the school principal with identifying and resolving } \\
\text { student issues, needs, and problems }\end{array}$ & 85.5 & 34.5 & 51.0 & 290 & 117 & 173 \\
\hline 5. Consultation, collaboration and teaming & 83.6 & 45.5 & 38.1 & 283 & 154 & 129 \\
\hline 6. School counseling program management and operation & 82.8 & 44.5 & 38.3 & 281 & 151 & 130 \\
\hline $\begin{array}{l}\text { 7. Education on understanding of self, including strengths and } \\
\text { weaknesses }\end{array}$ & 79.0 & 46.3 & 32.7 & 268 & 157 & 111 \\
\hline 8. Small group counseling & 74.9 & 39.8 & 34.8 & 253 & 135 & 118 \\
\hline 9. Referrals from school support to community resources & 73.7 & 45.4 & 28.3 & 250 & 154 & 96 \\
\hline 10. Career awareness, exploration and planning & 72.2 & 39.2 & 33.0 & 245 & 133 & 112 \\
\hline $\begin{array}{l}\text { 11. Academic support, including organizational, study and test } \\
\text { taking skills }\end{array}$ & 70.8 & 38.9 & 31.9 & 240 & 132 & 108 \\
\hline 12. Administration of cognitive aptitude and achievement tests & 68.1 & 33.0 & 35.1 & 231 & 112 & 119 \\
\hline 13. Interpretation of cognitive, aptitude and achievement tests & 67.0 & 35.7 & 31.3 & 227 & 121 & 106 \\
\hline 14. Multicultural/diversity awareness & 62.8 & 41.0 & 21.8 & 211 & 139 & 74 \\
\hline 15. Academic planning & 61.7 & 38.1 & 23.6 & 209 & 129 & 80 \\
\hline 16. Professional development & 52.5 & 36.3 & 16.2 & 178 & 123 & 55 \\
\hline 17. Assisting in special education services & 50.7 & 38.9 & 11.8 & 172 & 132 & 40 \\
\hline 18. Maintaining student records & 48.1 & 30.1 & 18.0 & 163 & 102 & 61 \\
\hline $\begin{array}{l}\text { 19. Analyzing grade point averages alignment in relationship to } \\
\text { achievement }\end{array}$ & 37.4 & 28.0 & 9.4 & 127 & 95 & 32 \\
\hline 20. Performing disciplinary actions & 12.7 & 10.9 & 1.8 & 43 & 37 & 6 \\
\hline
\end{tabular}

Note. I/VI = Important/Very Important; I = Important; VI = Very Important.

\section{Discussion}

Responsive Services seem to be especially valued by school administrators, with crisis counseling being of paramount importance (93\%). School counselors can use this information to pay special attention to proactive planning by enlisting the efforts of the school principal, as well as other school staff. The rating of crisis intervention as first in importance by the vast majority of all participants is similar to the findings of Fitch et al. (2001), where future school administrators similarly rated it as the top school counselor duty in regard to importance. As suggested by Fitch et al (2001), counselor educators can use this information when preparing school counselors as they may find additional training in crisis management of particular value in their future school setting. Assisting the school principal with identifying and resolving student issues was rated fourth $(85.5 \%)$, an indication on the importance that school principals may place on the school counselor's unique helping skills. 
Small group and individual counseling are also indicated as being given high importance by school principals, a finding also noted in other studies (Zalaquett, 2005; Amatea \& Clark 2005). These tasks pertain to one of the main counselor roles as indicated by ASCA (2003) - that of counseling.

In the School Guidance Curriculum category, the task of addressing peer relationships, coping strategies and effective social skills is rated the highest importance (91.7\%). This may indicate that school principals view the schools counselor's role (addressing students' academic, career and personal/social development) with perhaps more emphasis being placed on personal/social domain. While school counselors commonly pay special attention to students personal/social needs, the role of the school counselor is to address students' comprehensive developmental needs and overall student success. Maintaining high visibility in the addressing of students' career and academic development may promote a more descriptive perception regarding the role of the school counselor from administrators and other school staff.

It is also interesting to note that although the majority (62.8\%) rated multicultural/diversity awareness as "important" to "very important", $10 \%$ of all respondents $(\mathrm{N}=343)$ rated it of "little importance". This may indicate that diversity may not be as pronounced in this rural population, and education on issues of multiculturalism may not be considered of primary importance. Indeed, the overwhelming majority of our survey participants (93\%) were of a homogenous ethnic status. Communicating the importance of multicultural and diversity awareness to school administrators could be an effective way to promote change. Murray (1995) proposes arranging meetings with administrators, as well as other counselors, with the purpose of defining and prioritizing problems and conferring regarding appropriate possible solutions.

The majority of all respondents reported items falling under the System Support category such as consultation, collaboration and teaming (83.6\%) and school counseling program management and operation (82.8\%) as "important" to "very important”. This indicates that school principals' rating of these appropriate tasks are in accordance with one of the ASCA main roles of the school counselor - that of consulting. Also, the ratings seem to be congruent with the ASCA recommendation regarding the implementation of a comprehensive school counseling program and the carrying out of coordinating roles within the school and the community setting.

Under the System Support Category, professional development was rated as "important" to "very important" by $52.5 \%$ of all respondents. Although rated as important by the majority of participants, $12.4 \%$ of all respondents deemed it "of little importance." An explanation to this rating could be the cost and time that is associated with professional development of school counselors. Some rural principals may not only perceive it as an extra cost to already limited rural school budgets, but also time taken away from schools that may be understaffed and have many needs.

The majority of all respondents reported items falling under the Individual Student Planning category as "important" to "very important", suggesting that school principals are aware of the school counselor tasks that fall under this category and value those job responsibilities. Education on understanding of self, including strengths and weaknesses received a rating of important/very important by $79 \%$ of the participants.

The top five rated tasks include in order of importance: crisis counseling; peer relationships, coping strategies and effective social skills; individual counseling; assisting the school principal with identifying and resolving student issues, needs and problems; and consultation, collaboration and teaming. Counselor educators can use this information in preparing school counselors regarding what tasks their principals most value, while also training them to educate school principals regarding other tasks that should also be emphasized in a school setting.

It is interesting to note that the inappropriate task, administration of cognitive aptitude and achievement tests, was rated twelfth (68.1\%). Interpretation of test results is recognized as an appropriate school counseling task, however the actual administration is considered an inappropriate task. Our findings are similar to those of Pérusse et al. (2004), with administration of tests being endorsed as appropriate by the majority of secondary school principals. This is an indication that more advocacy on the part of the school counselors regarding the carrying out of this task may be needed.

Other inappropriate tasks, such as assisting in special education services, was rated seventeenth (50.7\%). Maintaining student records was rated eighteenth (48\%), and performing disciplinary actions was rated last (12.7\%). The carrying out of these tasks can prevent school counselors from delivering essential appropriate services and advance confusion regarding the role of the school counselor. The rating of disciplining as last was similar with the results found in a survey conducted by Fitch et al (2001), where future school administrators also rated the particular task as last. This might be an indication that while some inappropriate tasks are incorrectly rated as important, other inappropriate tasks with a history of creating role conflict for school counselors, such as disciplining, are no longer deemed as important by the majority of school principals.

Convenience, cost effectiveness, and a history of school counselors carrying out these duties may be some of the reasons that school principals continue to delegate those duties to school counselors (Baker, 2000). Advocacy by the school counselor to explain their role and function can be done through proactive activities such as in-service programs. Literature suggests that school administrators may benefit from a discussion regarding the re-evaluation of counselor role perceptions (Amatea \& Clark, 2005). 
Engaging school principals in counseling education can result in a deeper understanding and collaboration between the two professionals (Shoffner \& Williamson, 2000).

The analysis of the principals' perception regarding school counselor appropriate tasks revealed a positive view of school counselor roles and duties in rural schools. Although some inappropriate duties were still deemed as important, this information can be used by school counselors, school principals and counselor educators in order to provide a glimpse of how school principals view school counselor appropriate and inappropriate tasks in the school setting. This could lead to the consideration of what changes might be needed, such as school counselors' performance of testing, special education and record maintenance services.

Future school counselors can also be trained in educating school principals regarding appropriate professional tasks, while future school principals can be further educated in appropriate role expectations regarding school counselors. Recommendations from this study can also be used for both school counselors and administrators to establish better communication practices and to further facilitate understanding of their respective roles and responsibilities. Successfully meeting the needs of both students and the community can be best achieved through collaboration and teaming of these two vital educational leaders.

\section{Limitations/Future Research}

As with all self-report questionnaires, caution must be exercised when interpreting the data. The survey developed for the purpose of this study was not a commonly used instrument and lacked reliability data. Although the response rates were adequate, it is possible that only respondents with strong feelings regarding the counselor's role chose to participate. Since this research is conducted to measure only school principals' perception of the role of the school counselor in one state, it might affect the generalization of these results to other principal populations that do not share the pertinent demographics or unique geographical area as the respondents. Additionally, elementary school principals were over-represented in our study, and therefore a large number of responses represent their perceptions regarding the role of the school counselor.

Future research may address practicing school counselors' perception of appropriate and inappropriate tasks and whether their role perception is congruent with ASCA and literature sanctioned school counselor duties. Utilizing this survey in another state might be useful to determine whether there are significant differences that pertain to geographical areas or populations. A comparison between school administrators' perceptions in rural and urban settings might be of special interest.

\section{References}

Amatea, E.S. \& Clark, M.A. (2005). Changing schools, changing counselors: A qualitative study of school administrator's conceptions of the school counselor's role. Professional School Counseling, 9(1), 16-28.

American School Counselor Association (ASCA). (2003). The ASCA national model: A framework for school counseling programs (2nd ed.). Alexandria, VA: Author.

American School Counselor Association (ASCA). (2004a). Why secondary school counselors? Retrieved October 3, 2005, from http://www.schoolcounselor.org/ content.asp?contentid=233

American School Counselor Association (ASCA). (2004b). The role of the professional school counselor. Retrieved October 3, 2005, from http://www.schoolcounselor.org/ content.asp?contentid=240.

American School Counselor Association (ASCA). (2004c). Why elementary school counselors? Retrieved October 3, 2005, from http://www.schoolcounselor.org/ content.asp?contentid $=230$

American School Counselor Association (ASCA). (2004d). Why middle school counselors? Retrieved October 3, 2005, from http://www.schoolcounselor.org/ content.asp?contentid $=231$

Baker, S.B. (2000). School counseling for the 21-century (3rd ed.) Upper Saddle River, NJ: Prentice Hall.

Ballard, M.B. \& Murgatroyd, W. (1999). Defending a vital program: School counselors define their roles. National Association of Secondary School Principals, 83(603), 18-27.

Beale, A.V., \& McCay, E. (2001). Selecting school counselors: What administrators should look for in prospective counselors. Clearing House, 74, 257-261.

Campbell, C.A. \& Dahir, C.A. (1997). Sharing the vision: The ASCA national standards for school counseling programs. Alexandria, VA: American School Counselor Association.

Coy, D.R. (1999). The role and training of the school counselor: background and purpose. National Association of Secondary School Principals, 83(603), 29.

Dahir, A. D. (2000). The national standards for school counseling programs: A partnership in preparing students for the new millennium. National Association of Secondary School Principals, 84(616), 68-77.

Dillman, D.A. (2000). Mail and internet surveys. New York, NY: John Wiley \& Sons, Inc.

Duncan, K. (2003). Perceptions of the importance and utilization of clinical supervision among certified South Dakota school counselors. Dissertation Abstracts International. (UMI No. 3100582). ISBN: 0-496-481733.

Fitch, T., Newby, E., Ballestero, V., \& Marshal, J.L. (2001). Counselor Education and Supervision, 41, 89-99. 
Henderson, P., \& Gysbers, N.C. (1998). Leading and managing your school guidance program staff. Alexandria, VA: American Counseling Association.

Heppner, P. P., Kivlighan, D. M., \& Wampold, B. E. (1999). Research design in counseling. Belmont, CA: Wadsworth Publishing.

Herr, E. L. (2001). The impact of national policies, economics, and school reform on comprehensive guidance programs. Professional School Counseling, 4, 236-245.

Johnson, L.S. (2000). Promoting professional identity in an area if educational reform. Professional School Counseling, 4(1), 31-41.

Kirchner, G.L., \& Setchfield, M.S. (2005). School counselor's and school principal's perceptions of the school counselor's role. Education, 126(1), 10-17.

Lambie, G.W., \& Williamson L.L. (2004). The challenge to change from guidance counseling to professional school counseling: A historical proposition. Professional School Counseling, 8(2), 124-131.

Lieberman, A. (2004). Confusion regarding school counselor functions: School leadership impacts role clarity. Education, 124(3), 552-558.

McLaughlin, D. H., Huberman, M. B., \& Hawkins, E. K. (1997). Characteristics of Small and Rural School Districts. Washington, DC: U.S. Department of Education, National Center for Education Statistics.

Morissette, P. J. (2000). The experiences of the rural school counselor. Professional School Counseling, 3(3), 197208.

Murray, B.A. (1995). Validating the role of the school counselor. School Counselor, 43(1), 5-10.

Nardi, P.M. (2006). Doing survey Research. Boston, MA: Pearson Education, Inc.
Niebuhr, K.E., Niebuhr, R.E.. \& Cleveland, W.T. (1999). Principal and counselor collaboration. Education, 119(4), 674-678.

Paisley, O.P., \& McMahon, G. (2001). School counseling for the $21^{\text {st }}$ century: Challenges and opportunities. Professional School Counseling, 5(2), 106-116.

Pérusse, R., Goodnough, G.E., Donegan, J. \& Jones, C. (2004). Perceptions of school counselors and school principals about the national standards for school counseling programs and the transforming school counseling initiative. Professional School Counseling, 7(3), 152-161.

Ponec, D.L. \& Brock, B.L. (2000). Relationships among elementary school counselors and principals: A unique bond. Professional School Counseling, 3(3), 208-218.

Schmidt, J. J. (2003). Counseling in schools: Essential services and comprehensive programs (4th ed.) Boston: Pearson Education.

Sears, S. (1999). Transforming school counseling: Making a difference for students. NASSP Bulletin, 83(603), 47-53.

Seashore Luis, K., Jones, L.M. \& Barajas, H. (2001). Districts and schools as a context for transformed counseling roles. NASSP Bulletin, 85(625), 62-73.

Shoffner, M.F. \& Willaimson, R.D. (2000). Engaging preservice school counselors and principals in dialogue and collaboration. Counselor Education and Supervision, 40(2), 128-131.

US Census Bureau: State and County Quick Facts. (2006). Retrieved June 30 from http:/quickfacts.census.gov/qfd/states/46000.htm

Zalaquett, C.P. (2005). Principal's perceptions of elementary school counselor's role and functions. Professional School Counseling, 8(5), 451-457. 